\title{
Effect of Different Cooking Methods on Natural Antioxidants in Pumpkin (Cucurbita moschata) Products
}

\author{
Tesby,M.R.Lotfy ${ }^{1}$, Marwa,Z.Mahfouz ${ }^{1}$ \& M.M.Youssef ${ }^{2}$ \\ 1- Home Economics Dept., Fac. of Specific Education,University of Alexandria ,Egypt. \\ 2- Food Science and Technology Dept., Fac. of Agric., University of Alexandria,El-Shatby, \\ Alexandria,Egypt.
}

Received: 31 October, 2017

Revised: 10 December, 2017

Accepted: 21 December, 2017

\begin{abstract}
The present study aimed to investigate the effects of various cooking methods on antioxidant content and radical scavenging activity of pumpkin. Three heat treatments were applied, namely,blanching, and stir frying for cubes $(1.5 \times 1.5 \times 1.5 \mathrm{~cm})$ and roasting for slices $(0.5 \mathrm{~mm})$ to produce soup, juice and roasted pumpkin. The results indicated that carotenoids content ranged between 11,07 IU/100g (soup) and $892 \mathrm{IU} / 100 \mathrm{~g}$ (juice).Roasted product exhibited significantly $(P \leq 0.05)$ the least flavoniod content $(12.09 \mathrm{~g} / \mathrm{kg})$, while soup possessed significantly $(P \leq 0.05)$ the highest content $(17.96 \mathrm{~g} / \mathrm{Kg})$. Lycopene content $(0.15 \mathrm{mg} / 100 \mathrm{~g})$ was found to be significantly $(P \leq 0.05)$ the least (in soup produced from cubes blanched for 4 mins). In contrast, the counterpart raw juice had significantly $(P \leq 0.05)$ the highest lycopene content $(0.70 \mathrm{mg} / 100 \mathrm{~g})$. Total polyphenols content of stir fried product was significantly $(P \leq 0.05)$ the least $(406.25 \mathrm{~g} / \mathrm{kg})$, while roasted product exhibited significantly $(P \leq 0.05)$ the highest polyphenols content $(670.18 \mathrm{~g} /$ $\mathrm{kg})$. It was obvious that raw juice possessed significantly $(P \leq 0.05)$ the highest DPPH $(63.79 \%)$, on contrary to roasted product being significantly $(P \leq 0.05)$ the least antioxidant activity as assessed by DPPH method $(30.31 \%)$. The $\mathrm{H}_{2} \mathrm{O}_{2}$ scavenging $(2.85 \%)$ was found to be significantly $(P \leq 0.05)$ the highest ( in soup produced from cubes blanched for 4 $\mathrm{min})$. While, the raw juice has significantly $(P \leq 0.05)$ the least $\mathrm{H}_{2} \mathrm{O}_{2}$ scavenging $(0.32 \%)$. So, It is necessary to apply the most proper cooking conditions (temperature and cooking time) to avoid any degradation of the bioactive compounds present in pumpkin. The results revealed the superiority of blanching process since it maintained the bioactive compounds in pumpkin without any deteriorative effects.
\end{abstract}

Keywords: Natural antioxidants, antioxidant activity, cooked pumpkins, blanching, stir-frying, juicie,soup,roasting.

\section{INTRODUCTION}

The tent "let food be the medicine and medicine be the food," espoused by Hippocrates nearly 2.500 years ago, is receiving renewed interest. It is worth to mention that there is a consumer interest in functional foods from the health point of view (Hasler, 1998, Anonymous, 2009). Antioxidants are compounds that protect cells against the damage effects of reactive oxygen species. It is worth to mention that some antioxidants are found in vegetables. In this respect, products high in vitamin $\mathrm{C}$, vitamin $\mathrm{E}$ and carotene content (provitamin A) are believed to be the most beneficial antioxidants (Palace et. al. 1999).

Pumpkin (Cucurbita moschata) is defined as a fruit botanically. Flesh and seeds of pumpkin are commonly used for culinary and medicinal purposes. Carotenoids are responsible for the orange colour of pumpkin. Murkovic et. al. (2002) reported that three species of pumpkin (Cucurbitapepo, C. maxi- ma and $C$. moschata) contained $\beta$-carotene (0.06-7.4 $\mathrm{mg} / 100 \mathrm{~g}), \alpha$-carotene $(0-7.5 \mathrm{mg} / 100 \mathrm{~g})$ and lutein $(0$ $17 \mathrm{mg} / 100 \mathrm{~g})$. Similarly, it was reported that pumpkin contains both $\beta$-carotene and lycopene. Pumpkin is cooked or pureed, and has numerous culinary uses either as a vegetable or as an ingredient in many food products. Fresh pumpkins are very sensitive to microbial spoilage, even at refrigerated conditions, and thereby they must be frozen or dried (Doymaz, 2007).

Food preparation at home, in particular, cooking is often the final step in food processing. Various cooking methods were found to affect content of phytochemicals, in particular, antioxidants present in the vegetables (Ismail et. al. 2004, Zhang \& Hamauzu, 2004, Turkmen et. al. 2005). Notwithstanding, Podşedek (2007) suggested that both antioxidant levels and activities of processed vegetables were lower than those of the corresponding fresh samples. This is probably attributed to degradation 
of the bioactive compounds and adsorption of water during boiling, resulting in dilution of the active compounds. Moreover, a significant increase was reported in release of $\beta$-carotene and tocopherol in broccoli upon cooking. Antioxidants inhibit oxidation of lipids by transforming free radicals/ peroxy radicals into non-radicals by donating electron and hydrogen or by chelating transition metals (Frankel, 1998). Several synthetic antioxidants are available in the market. Due to their reported carcinogenic effects, use of such antioxidants is restricted. Moreover,synthetic antioxidants may cause kidney damage (Branen, 1975, Ito et al. 1983, Lindenschmidt et al., 1986). Consequently, it is necessary to search for new natural antioxidants as an alternative to synthetic antioxidants to prevent lipid oxidation in foods (Farvin et al. 2014).Many epidemiological studies have indicated that the oxidative stress imposed by reactive oxygen stress species (ROS) plays an important role in many chronic and degenerative diseases, (Young \& Wood, 2001, Azizova, 2002, Fu et al., 2011., Zhang \& Tsao, 2016)

The present study aimed at investigation the effect of various cooking methods (blanching, stirfrying and roasting) on the antioxidants content and potency of pumpkins

\section{MATERIALS AND METHODS}

\section{Materials}

Fresh pumpkin (Cucurbita moschata) of commercial maturity was obtained in July 2014. Representative sample was withdrawn from the Central Market of Vegetables and Fruits. Alexandria Governorate, Egypt. Other ingredients were purchased from Alexandria market, Egypt.

All chemicals and reagents used in the present study were purchased from El-Gomhoria Company for Chemicals, Alexandria, Egypt, except for DPPH reagent (1,1- dipheny1 -2 picry1 hydrazy1) which was obtained from Sigma Company, Germany.

\section{Preparation of samples:}

Pumpkin fruits were carefully washed with tap water, dried with a soft cloth and the skin was peeled. The seeds were removed from the pulp using knife, then the pulp was washed thoroughly with distilled water and cut into small pieces " cubes" $(1.5 \times 1.5 \times 1.5 \mathrm{~cm})$, and slices $(0.5 \mathrm{~mm})$, One portion was retained raw while others were used to prepare different products (Juice, soup, fried and roasted).

\section{Preparation of pumpkin products:-}

Raw juice (RJ), boiled juice (BJ), boiled soups (BS), roasted (RO-P) and stir fried pumpkin (SF-P) were prepared according to the methods shown in Fig. (1).

\section{Cooking methods}

Three thermal treatments were used including boiling, stir- frying, roasting along with fresh samples as a control. For preparing soup, $2.800 \mathrm{Kg}$ of pulp cubes were blanched in boiling water $\left(100^{\circ} \mathrm{C}\right)$ for 2,4, 6 min. Meanwhile, traditional soup was prepared by boiling in water $\left(100^{\circ} \mathrm{C}\right)$ for 20 mins. The chopped raw onion, garlic, carrots and celery were fried in corn oil until these ingredients have golden colour, and then the other ingredients were cooked for $8 \mathrm{~min}$ and added to blanched cubes to make soup. Ingredients used in preparation of pumpkin soup are shown in Table (1). Boiling was conducted for 4 and $2 \mathrm{~min}$.

\section{Analytical methods}

\section{Determination of lycopene}

For extracting lycopene, one $g$ of homogenized fresh or semi -dried pumpkin sample was weighed

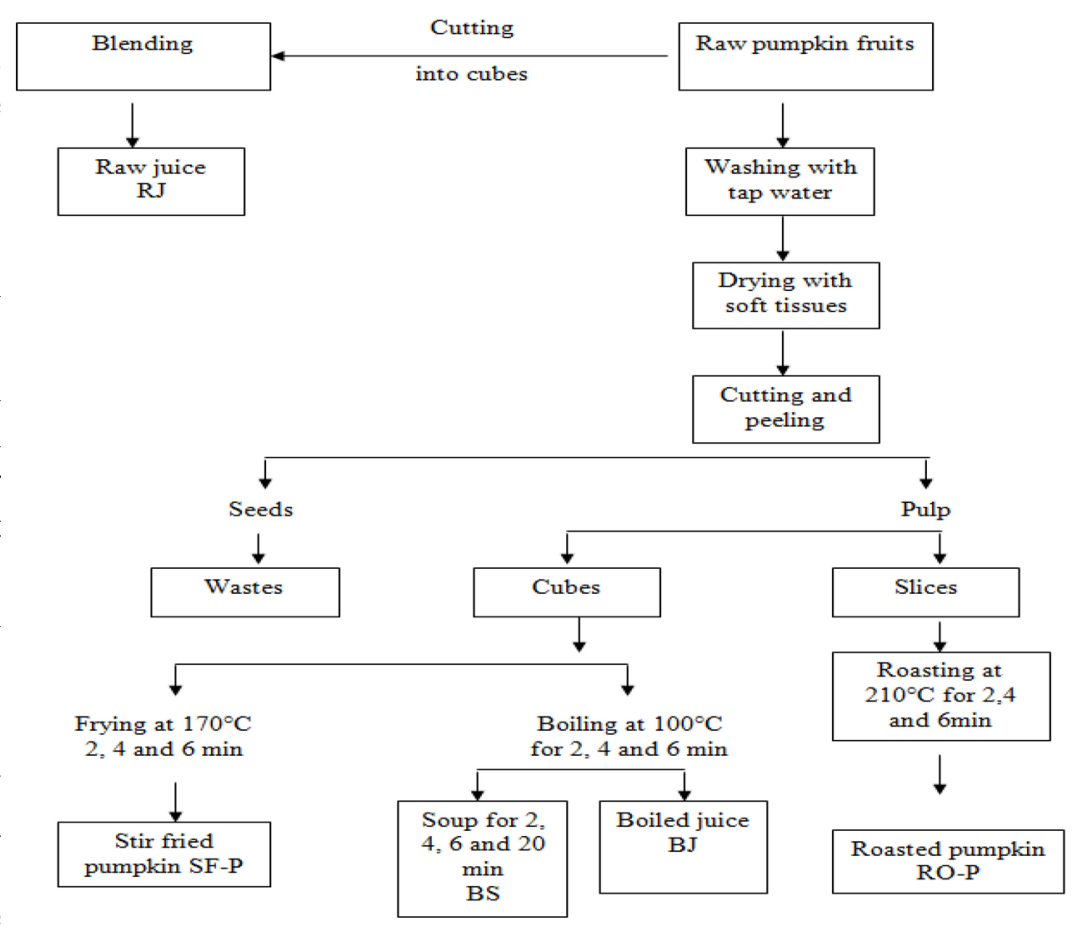

Fig. 1: Flow sheet of preparation methods of pumpkin products 
Table 1 : Ingredients used in the preparation of pumpkin soup

\begin{tabular}{ll}
\hline \multicolumn{1}{c}{ Ingredient } & Quantity (g) \\
\hline Blanched cubes of pumpkins & 700 \\
Chopped raw carrots & 27.30 \\
Chopped raw onion & 70.6 \\
Cinnamon & 0.1 \\
Cloves & 0.17 \\
Chopped raw garlic & 2.8 \\
Black pepper & 0.23 \\
Ginger & 0.3 \\
Corn oil & 7 \\
Cumin & 0.1 \\
Food salt & 6.5 \\
Cardamom & 0.5 \\
Celery & 92.5 \\
Water & $500(\mathrm{ml})$ \\
\hline
\end{tabular}

into a screw-top tube, which was covered with aluminum foil to exclude light. The 1ycopene from the samples was extracted according to the method of Sadler et al. (1990) using $25 \mathrm{ml}$ mixture of hexane - acetone- ethanol (2:1:1:,v:v:v) .

Lycopene was determind by Shimadzu spectrophotometer. The absorbance was measured at $503 \mathrm{~nm}$ and hexane was used as blank .Lycopene content was calculated using lycopene extinction coefficient (E\% 3150) according to the method described by Chang \& Liu (2007).

\section{Determination of total corotenoids}

Total carotenoids (mg 100g) were determined by a modified method of Ranganna (1997). Acetone and petroleum ether were used as extracting solvents and the absorbance was measured at 450nm.

\section{Determination of total polyphenols}

The method of Skerget et al. (2005) was applied to extract polyphenols with some modifications. Approximately $5 \mathrm{~g}$ sample was extracted using $50 \mathrm{ml}$ ethanol in $250 \mathrm{ml}$ conical flask. The flask was placed in a water bath at $25^{\circ} \mathrm{C}$ for $1 \mathrm{hr}$. the crude extract was then filtered through a 0.4 um filter (Whatman, Maidstone, England) and the solvent was then evaporated under vacuum. The extraction yield was then determined as $\%$ weight. The extracts were kept at $-20^{\circ} \mathrm{C}$ until analysis.

Total polyphenolics content was determined byFolin- Ciocalteu method (AOAC. 1990).

\section{Determination of total flavonoids com- pounds (TFC)}

The method of Ordon et.al. (2006) was used to determine the total flavonoid content (TFC). A volume of $0.5 \mathrm{ml}$ of $2 \% \mathrm{AlCl}_{3}$ ethanol solution was added to $0.5 \mathrm{ml}$ of the supernatant. After $1 \mathrm{hr}$ of incubation at the room temperature, the absorbance was measured at $420 \mathrm{~nm}$ using Shimadzu spectrophotometer.

\section{Determination of antioxidant activities}

\section{The DPPH radical scavenging activity}

The method of Brand-Williams et al. (1995) with some modifications was used to measure free radical scavenging activity. The extracts were dissolved in $1.0 \mathrm{ml} \mathrm{MeOH}$ and the solutions were added to a $1.0 \mathrm{ml} \mathrm{DPPH}$. The absorbance at $515 \mathrm{~nm}$ was measured using Shimadzu Spectrophotometer. The following equation was applied to calculate DPPH scavenging activity:

DPPH scavenging activity $(\%)=\left[\left(\mathrm{A}_{0}-\mathrm{A}_{\mathrm{t}}\right) / \mathrm{A}_{0}\right] \times 100$

Where $A_{0}$ is the absorbance of the control at $\mathrm{t}=0 \mathrm{~min}$, and $\mathrm{A}_{\mathrm{t}}$ is the absorbance of the antioxidant at $\mathrm{t}=15 \mathrm{~min}$.

\section{Hydrogen peroxide scavenging activity}

The modified method of Ngonda (2013) was used to measure the scavenging activity of extract towards hydrogen peroxide radicals. The percentage of hydrogen peroxide scavenging by the extract and standard compound was calculated using the given formula:

Percentage scavenged $\left[\mathrm{H}_{2} \mathrm{O}_{2}\right]=1$ - Abs (standard) / Abs (control) $\times 100$ where, Abs is the absorbance of the control (without extract) at $560 \mathrm{~nm}$, Abs (sample) is the absorbance in the presence of the extract at $560 \mathrm{~nm}$.

\section{Statistical analysis}

Data were fed to the computer and analyzed using IBM SPSS software package version 20.0. (Kotz, et al. 2006 \& Kirkpatrick and Feeney, 2013), with one way ANOVA.

\section{RESULTS AND DISCUSSION}

The present study was conducted on four pumpkin products namely,juice,soup, stir-fried and roasted. Such products were subjectively evaluated along with the control. The highest ranked treatments were investigated in the present study, including( 1-Juice:boiling for 2 mins, 2-Soup: boil- 
ing for $4 \mathrm{~min}, 3-\mathrm{Stir}$ fried:stir fried for $2 \mathrm{~min}$ and 4- Roasted:roasting for $4 \mathrm{~min}$.) as figured out in our previous study (Lotfy et al, 2016).

\section{Antioxidant activity and phytochemicals of pumpkin and its products:}

\section{Antioxidant activity}

Pumpkin seems to be promising as antioxidants containing food. However, it was obvious that pumpkin and its products could serve as a good source of antioxidants. According to Moharram \& Youssef (2014), antioxidant capacity should be evaluated by more than one method to trace the different mechanisms of free radicals scavenging. In the present study, DPPH- scavenging values of pumpkin products ranged from $30.31 \%$ (roasted pumpkin chips) to $63.79 \%$ (raw juice) (Table 2). The $\mathrm{H}_{2} \mathrm{O}_{2}$ scavenging values varied from $0.32 \%$ to $2.85 \%$ for the raw juice and soup boiled for $4 \mathrm{~min}$, respectively, (Table 2). It was obvious that blanching process was superior in terms of maintaining the antioxidant potency of pumpkin as compared to both stir frying and roasting. Consequently, blanching is favourable method of cooking for pumpkin.

\section{Phytochemicals:}

\section{Carotenoids}

The carotenoids content of pumpkin and its products are presented in Table (3). The raw pumpkin juice (RJ-P) exhibited significantly $(P \leq 0.05)$ the highest carotenoids content (1476 IU/ 100g). On the other hand, the least significantly $(P \leq 0.05)$ carotenoids content was found in roasted pumpkin for $4 \mathrm{~min}(584.00 \mathrm{IU} / 100 \mathrm{~g})$. The other products could be ascendingly ordered in terms of their carotenoid content as follows: (IU/100 g): Raw-P (raw pumpkin) (1200), BS-P (soup boiling for 4 min) (1107), BJ-P (juice boiling for $2 \mathrm{~min}$ ) (892), P-ST(boiling soup for 20 mins) (830) and SF-P (stirring fried for $2 \mathrm{~min}$ ) (676).

Pumpkins are a good source of provitamin A. The high content of provitamin A in pumpkins can be utilized by availing the pumpkins to the markets worldwide, device cultivation methods for large production and determined conditions for long storage shelf life (Karanja et.al. 2012).

Carotenoids possess nutritional properties and health promoting effects. Pumpkins flesh has an intense yellow/ orange colour owing to the high level of carotenoids, mainly $\alpha$-carotene, $\beta$-carotene, $\beta$-cryptoxanthin, lutein, lycopene and zeaxanthin
Table 2: Antioxidant activity of pumpkin and its products

\begin{tabular}{lll}
\hline \multicolumn{1}{c}{ Treatment } & \multicolumn{1}{c}{ DPPH\% } & Scavenged $\mathbf{H}_{2} \mathbf{O}_{\mathbf{2}} \%$ \\
\hline Raw-P & $61.69 \pm 0.16^{\mathrm{b}}$ & $0.99 \pm 0.84^{\mathrm{bc}}$ \\
RJ & $63.79 \pm 0.47^{\mathrm{a}}$ & $0.32 \pm 0.03^{\mathrm{c}}$ \\
BJ & $36.84 \pm 0.33^{\mathrm{e}}$ & $2.30 \pm 0.79^{\mathrm{ab}}$ \\
BS & $59.58 \pm 0.72^{\mathrm{c}}$ & $2.85 \pm 0.35^{\mathrm{a}}$ \\
TS & $37.89 \pm 0.56^{\mathrm{e}}$ & $1.84 \pm 0.33^{\mathrm{ab}}$ \\
SF & $46.44 \pm 0.08^{\mathrm{d}}$ & $1.02 \pm 0.74^{\mathrm{bc}}$ \\
RO & $30.31 \pm 0.05^{\mathrm{f}}$ & $1.71 \pm 0.65^{\mathrm{bc}}$ \\
Mean & 48.076 & 1.574 \\
C.V & 1.047 & 38.065 \\
F & $2192.32^{*}$ & $6.211^{*}$ \\
P & $<0.0001^{*}$ & $<0.001^{*}$ \\
\hline
\end{tabular}

Values are expressed as means \pm SD.

Mean in a column not sharing the same superscript are significantly different at $P \leq 0.05$

Raw-P: control TS: boiling soup for $20 \mathrm{~min}$ RJ: raw juice $\quad \mathrm{SF}$ : stirring fried for $2 \mathrm{~min}$

BJ: boiling juice for 2 min

RO: roasting pumpkin for $4 \mathrm{~min}$

BS: boiling soup for $4 \mathrm{~min}$

(Durante et al. 2014). It is worth to mention that the total carotenoids content (on dry weight basis) of the pumpkins peel depends on variety being in a range of 12 to up to $175 \mathrm{mg} / \mathrm{kg}$ (Kreck et al. 2006).

Lycopene content $(\mathrm{mg} / 100 \mathrm{~g})$ ranged from 0.15 (soup boiled for $20 \mathrm{~min}$ ) to 0.70 (raw pumpkin juice) as shown in Table (3). Significant differences $(P \leq 0.05)$ could be traced in lycopene content of the different pumpkin products. It was obvious that boiling for $4 \mathrm{~min}$, stir- frying for $2 \mathrm{~min}$ and roasting for $4 \mathrm{~min}$ significantly $(P \leq 0.05)$ lowered the lycopene content of pumpkin (Table 3 ).

The $\beta$-carotene contents in pumpkin products investigated in the present study ranged from 98.59 to $6834.9 \mathrm{IU} / 100 \mathrm{gm}$. It is worth to mention that the high content of carotenoids in RJ-P may be attributed to increase the surface area as a result of disintegration that occurred in blending process. No $\beta$-carotene could be detected in both TS-P (soup boiled for $20 \mathrm{~min}$ ) and SF-P (stirring fried for 2 mins), it was clear that heat applied in the preparation of these pumpkin products affected negatively the $\beta$-carotene content. The most pronounced effect was that for boiling for $20 \mathrm{~min}$ to prepare soup and stir frying for 2 min to prepare stir-fried pumpkin (Table 3). 
Table 3: Total carotenoids, lycopene and $\beta$ carotene contents of the products prepared from pumpkins

\begin{tabular}{llll}
\hline Sample & $\begin{array}{c}\text { Total carotenoids } \\
(\mathrm{IU} / 100 \mathrm{~g})\end{array}$ & $\begin{array}{c}\text { Lycopene } \\
(\mathrm{mg} / 100 \mathrm{~g})\end{array}$ & $\begin{array}{c}\beta \text {-carotene* } \\
(\mathrm{IU} / 100 \mathrm{~g})\end{array}$ \\
\hline Raw-P & $1200 \pm 0.27^{\mathrm{b}}$ & $0.65 \pm 0.14^{\mathrm{a}}$ & 845.30 \\
RJ & $1476 \pm 0.08^{\mathrm{a}}$ & $0.70 \pm 0.07^{\mathrm{a}}$ & 6834.94 \\
$\mathrm{BJ}$ & $892 \pm 0.56^{\mathrm{d}}$ & $0.18 \pm 0.02^{\mathrm{bc}}$ & 98.59 \\
$\mathrm{BS}$ & $1107 \pm 0.47^{\mathrm{c}}$ & $0.54 \pm 0.08^{\mathrm{a}}$ & 602.04 \\
$\mathrm{TS}$ & $830 \pm 0.27^{\mathrm{e}}$ & $0.15 \pm 0.06^{\mathrm{c}}$ & Not detected \\
$\mathrm{SF}$ & $676 \pm 0.05^{\mathrm{f}}$ & $0.35 \pm 0.03^{\mathrm{b}}$ & Not detected \\
RO & $584 \pm 0.74^{\mathrm{g}}$ & $0.17 \pm 0.05^{\mathrm{bc}}$ & 566.86 \\
Mean & 967.025 & 0.3959 & \\
C.V & 0.435 & 19.19 & \\
$\mathrm{~F}$ & $1656948^{*}$ & $30.20^{*}$ & \\
$\mathrm{P}$ & $<0.0001^{*}$ & $<0.0001^{*}$ & \\
\hline
\end{tabular}

Values are expressed as means \pm SD.

Means in column not sharing the same superscript are significantly different at $P \leq 0.05$.

Raw-P: control

$\mathrm{RJ}$ : raw juice

$\mathrm{BJ}$ : boiling juice for $2 \mathrm{~min}$

BS: boiling soup for $4 \mathrm{~min}$

TS: boiling soup for $20 \mathrm{~min}$

SF: stirring fried for $2 \mathrm{~min}$

RO: roasting pumpkin for $4 \mathrm{~min}$

The data presented here regarding the effect of boiling and stir- frying on carotenoids content of pumpkins are not in agreement with data of Azizah et al. (2009). They found that the aforementioned treatments elevated the contents of both $\beta$-Carotene ( 2 to 4 times) and lycopene (17 to 40 times) of pumpkin after cooking for 2, 4 and 6 min.It is well known that numerous factors affect the stability of carotenes in food. Temperature, oxygen and duration of heat treatment are the main factors in this respect. Consequently, cooking of pumpkins by different methods (blanching, stir-frying and roasting) vary in terms of their effects on the stability of carotenes.

\section{Flavonoides and phenolic compounds}

Table (4) shows that each of Raw -P, RJ-P and P-ST possessed significantly $(P \leq 0.05)$ the highest content of flavonoids. The other pumpkin products had flavonoids contents ranged from 12.09 to $14.64 \mathrm{~g} / \mathrm{kg}$.

Data in Table (4) show that raw - Pand RJ-P exhibited significantly $(P \leq 0.05)$ the highest polyphenolies content being $670.18 \mathrm{~g} / \mathrm{kg}$, followed by Raw-P (530.32, RO-P (518.22) TS-P (440.86),
Table 4: Flavonoids and phenolies contents of pumpkins and its products

\begin{tabular}{lll}
\multicolumn{1}{r}{ Treatment } & Flavonoids $(\mathrm{g} / \mathrm{kg})$ & \multicolumn{1}{c}{ Phenols $(\mathrm{g} / \mathrm{kg})$} \\
\hline Raw-P & $17.24 \pm 0.46^{\mathrm{a}}$ & $530.32 \pm 0.10^{\mathrm{b}}$ \\
RJ & $17.96 \pm 0.76^{\mathrm{a}}$ & $670.18 \pm 0.61^{\mathrm{a}}$ \\
$\mathrm{BJ}$ & $13.53 \pm 0.78^{\mathrm{bc}}$ & $430.26 \pm 0.40^{\mathrm{e}}$ \\
$\mathrm{BS}$ & $17.18 \pm 0.17^{\mathrm{a}}$ & $411.25 \pm 0.44^{\mathrm{f}}$ \\
TS & $14.64 \pm 0.85^{\mathrm{b}}$ & $440.86 \pm 0.10^{\mathrm{d}}$ \\
SF & $13.59 \pm 0.86^{\mathrm{bc}}$ & $406.25 \pm 0.85^{\mathrm{g}}$ \\
RO & $12.09 \pm 0.61^{\mathrm{c}}$ & $518.22 \pm 0.69^{\mathrm{c}}$ \\
Mean & 15.177 & 486.76 \\
C.V & 4.502 & 0.108 \\
F & $33.15^{*}$ & $97051.59^{*}$ \\
P & $<0.0001^{*}$ & $<0.0001^{*}$ \\
\hline
\end{tabular}

Values are expressed as means \pm SD.

Mean in a column not sharing the same superscript are significantly different at $P \leq 0.05$

Raw-P: control

TS: boiling soup for $20 \mathrm{~min}$

RJ: raw juice

BJ: boiling juice for $2 \mathrm{~min}$

BS: boiling soup for $4 \mathrm{~min}$

SF: stirring fried for $2 \mathrm{~min}$

RO: roasting pumpkin for $4 \mathrm{~min}$

BJ-P (430.26), BS-P (411.25) and SF-P (406.25) g/ $\mathrm{kg}$. It is well known that several phenols, i.e. nonflavonoids mainly drived from cinamic acid, are part of the plant antioxidant system. Most common hydroxycinnamates are $p$-coumaric, caffeic, ferulic as well as caffeoylquinic acid and chlorogenic acid.

Data presented here regarding the effect of boiling and stir- frying on total phenols of pumpkins are in accordance with data published by Azizah et.al. (2009), who found that the aforementioned treatments resulted in 18 to $54 \%$ lossess of total phenolics content of the pumpkins.

\section{CONCLUSIONS}

Pumpkin pulp can be prepared in many forms (juice, soup, stir-fried cubes and roasted chips). It was obvious that all these aforementioned forms were well accepted by panelists. Due to presence of bioactive compounds mainly dietary fibers and antioxidants, it is advisable to promote and encourage consumption of pumpkin dishes in Egypt.

\section{Recommendations}

Based on the results of the present work, the 
following recommendations are suggested:

$1-$ It is necessary to apply the most proper cooking conditions (temperature and cooking time) to avoid any degradation of the bioactive compounds present in pumpkins. Study reveal the superiority of blanching since it maintained the bioactive compounds in pumpkins without deteriorative effects.

2- Promotion and encourage the consumption of different pumpkin products in Egypt, since these products are considered as functional foods and thereby protect against many degenerative diseases.

\section{REFERENCES}

Anonymous 2009. The quest for optimal health: What you need to know about functional foods. (Dairy council of California www. Meals-matter.org, (American dietetic Association) www.eatright.org, (Functional foods for Health program by University of Illinois at urbanacham-paign ad Chicago) www.ag.uiuc.edu/ ffh/, (International food Information council) www.ific.org.

AOAC 1990. Official methods of Analysis of the Association of Analytical Chemists, Kenneth Herlich (Ed) Arlington Virginia. 22201,USA.

Azizah, A. H., Wee, K. C., Azizah, O. \& Azizah, M. 2009. Effect of boiling and stir frying on total phenolics, carotenoids and radical scavenging activity of pumpkin (Cucurbita moschato). International Food Research Journal, 16: 45-51.

Azizova, O. N.2002. Role of free radical process in the development of a hero sclerosis. BiologicheskieMem- brany, 19: 451-471.

Brand-Williams, W., Cuvelier, M. E. \& Berset, C. 1995. Use of a free radical method to evaluate antioxidant activity.Lebensmittel-wissenschaft and Technologie, 28:25-30.

Branen, A. L. 1975. Toxicology and biochemistry of butylatedhydroxy anisole and butylatedhydroxy toluene. Journal of Americam oil Chemist Society, 52: 59-63..

Chang, C. H. \& Liu, Y.C. 2007. Study on lycopene and antioxidant contents variations in tomatoes under air-drying process. Journal of Food Science, 72:E532-E540.

Doymaz I. 2007. The kinetics of forced convective airdrying of pumpkin slices. Journal of Food Engi- neering, 79, 243-248.

Durante, M., Lenucci, M.S., D'Amico, L. \& Piro, G. \& Mita, G. 2014. Effect of drying and co-matrix addition on the yield and quality of supercritical $\mathrm{CO}_{2}$ extracted pumpkin (Cucurbita moschata.) oil. Food Chemistry, 148:314-320.

Farvin -Sabeena, K. H., Andersen, L. L., Nielsen, H. H., Jacobsen, C., Jakobsen, G., Johansson, I., \& Jessen, F. 2014. Antioxidant activity of Cod (Gadusmorhua) protein hydrolysates: Part 1 - In vitro assays and evaluation in 5\% fish oil-in water emulsion. Food Chemistry, 149: 326-334.

Frankel, E. N. 1998.Lipid Oxidation. Dundee, UK: The Oily Press.Lipid Oxidation. Dundee, UK: The Oily Press.

Fu, L., Xu, B. T, Xu, X-R, Gan, R. Y, Zhang, Y Xia, E. Q. \& Li, H. B. 2011. Antioxidant capacities and total penalice contents of 62 fruits. Food Chemistry, 129: 345-350.

Hasler, M. 1998. Functional foods: Their role in disease prevention and health promotion. Food Technology, 52: 57-62.

Ismail, A., Marjan, Z. M. \& Foong, C.W. 2004.Total antioxidant activity and phenolic content in selected vegetables. Food Chemistry 87: 581-586.

Ito, N., Fukushima, S., Hasegawa, A., Shibata, M., \&Ogiso, T. 1983. Carcinogenicity of butylated hydroxy anisole in F344 rats. Journal of the National Cancer Institue, 70, 343-347.

Karanja, J.K., Mugend, J.B., Fathiya, M.K. \& Muchug, A.N. 2012 Comparative study on the nutritional value of the pumpkin (cucurbita maxima) varieties from different regions, proceedings 7 nth JKUAT Scientific and Industrialization conference 15-16 nth November, AICAD Nairobi-Kenya.

Kirkpatrick, L.A. and Feeney, B.C. 2013. A simple guide to IBM SPSS statistics for version 20.0. Student ed. Belmont, Calif.: Wadsworth, Cengage Learning.

Kotz, S., Balakrishnan, N., Read, C.B. \& Vidakovic, B. 2006. Encyclopedia of statistical sciences. 2nded. Hoboken, New Jersey: WileyInterscience.

Kreck, M., Kürbel, p, Ludwig, M, Paschold, P.J. \& Dietrich, H. 2006. Identification and quantification of carotenoids in pumpkin cultivars (Cucurbita maxima L), and their juices by 
liquid chromatography with ultraviolet- diode array detection. Journal of Applied Botany and Food Quality, 80: 93-99.

Lindenschmidt, R.C, Tryka, A.F., Goad, M.E. \& Witschi,H.P. 1986. The effects of dietary butylatedhydroxytoluene on liver and colon tumor development in mice.Toxicology, $\mathbf{3 8}$ : 151-160.

Lotfy,T.M1.,Mahfouz,M.Z1.\&Youssef ,M.M . 2016. Effects of cooked pumpkin, functional food as hypoglycemic and hypolipidemic factors on diabetic rats.XXIII IFHE World Congress,Daejeon, Korea.

Moharram H.A. \& Youssef, M.M. 2014. Methods for determining the antioxidant activity: A Review. Alexandria Journal of Food Sciance\&Technology., 11: 29-39.

Murkovic, M., Mulleder, U. \& Neunteufl, H. 2002. Carotenoid content in different varieties of pumpkins. Journal of Food Composition and Analysis, 15: 633-638.

Ngonda, F. 2013.In-vitro Anti-oxidant activity and free radical scavenging potential of roots of Malawian Trichodesmazeylanicumm (burn. F.). Asian Journal of Biomedical and Pharmaceutical Scienes, 3: 1-5.

Ordon Eg,A.A.L., Gomeg , J.D., vattuone , M.A \& Isla, M.L. 2006. Antioxidant activities of sechiumedule (Jacq). Food Chemistry., 97:452-458.

Palace, V. P., N. Khaper, Q. Qin, P. K. Singal, 1999. Antioxidant potentials of vitamin A and carotenoids and their relevance to heart disease. Free Radical Biology and Medicine. 25, 746-761.

Podşedek,A.2007.Naturalantioxidants and antioxidant capacity of Brasic ca vegetables:A review.LWT Food Science, 40:1-11

Ranganna, S. 1997. Manual of analysis of fruit and vegetable products 9thed. New Delhi: McGraw Hill.

Sadler, G., Davis, J. \& Dezman, D. 1990.Rapid extraction of lycopene and $\beta$-carotene from reconstituted tomato past and pink grapefruit homogenate. Journal of Food Science. 55:1460-1461.

Skerget, M., Kotnik, P., Hadolin, M., Hras, A., Simonic, M. \& Kenz, Z. 2005. Phenols, proanthocyanidins, flavones and flavonols in some plant materials and their antioxidant activities. Food Chemistry, 89: 191-198.

Turkmen, N., Sari, F. \& Velioglu, S. 2005. The effect of cooking methods on total phenolics and antioxidant activity of selected green vegetables. Food Chemistry 93: 713-718.

Young, I.S, \& Woodside, J.V 2001. Antioxidants in health and disease.Journal of Clinical Pathology, 54: 176-186.

Zhang, D. \& Hamauzu, Y. 2004.Phenolics, ascorbic acid, carotenoids and antioxidant activity of broccoli and their changes during conventional and microwave cooking. Food Chemistry, 88: 503-509.

Zhang, H.\&Tsao,R.2016. Dietary polyphenols, oxidative stress and antioxidant and anti-inflammatory effects. Current Opinion in Food Science, 8:33-42. 


\section{تأثير طرق الطهو المختلفة على مضاد ات الأكسلة الطبيعية في منتجات القرع العسلي}

تسبي محمد رشاد لطفي(1)، مروة زكي محفوظ علي(1)، محمد محمود يوسف(r)

ا - قسم الاقتصاد المنزلي - كلية التر بية النوعية- جامعة الإسكندرية.

r- قسم علوم وتقنية الأغذية -كلية الزراعة- جامعة الإسكندرية .

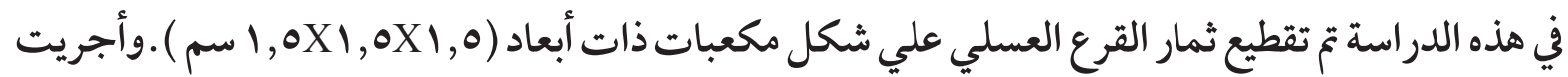

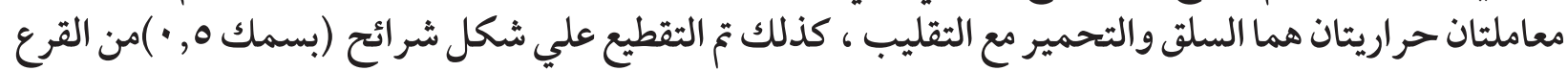

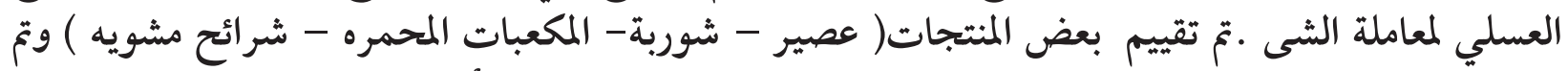

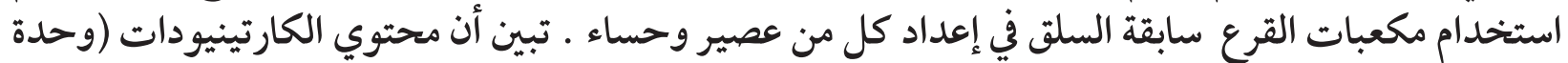

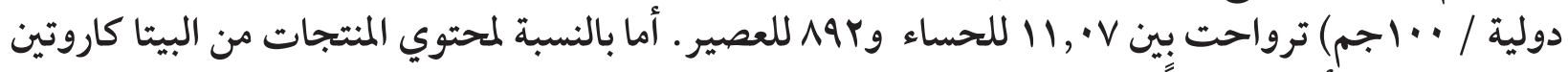

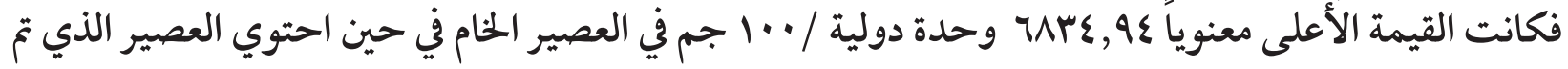

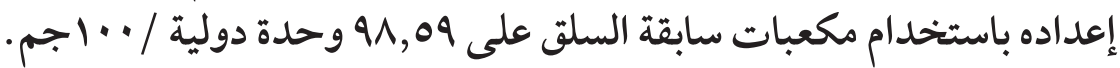

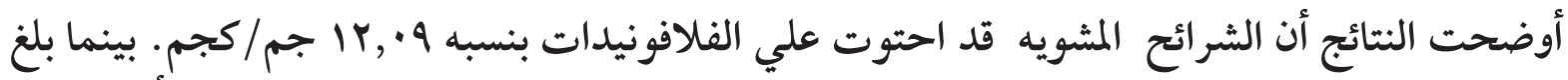

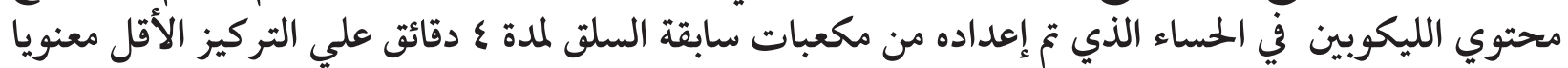

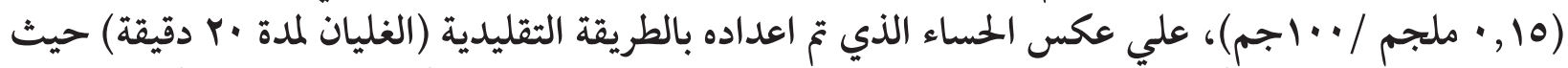

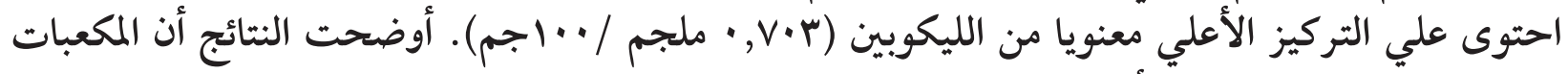

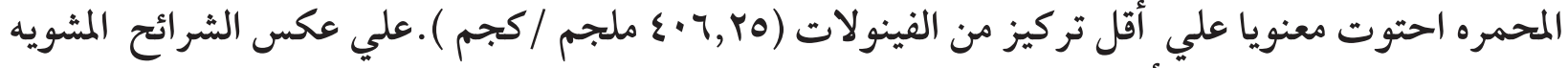

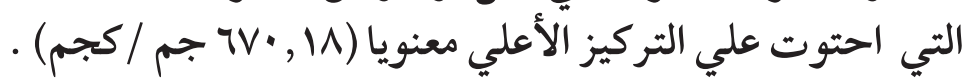

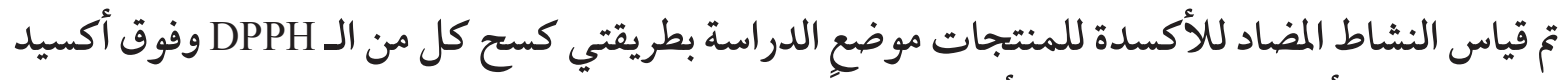

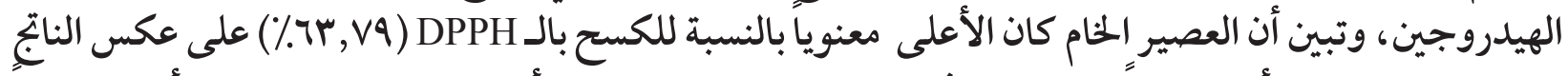

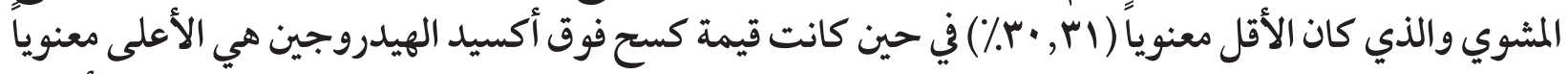

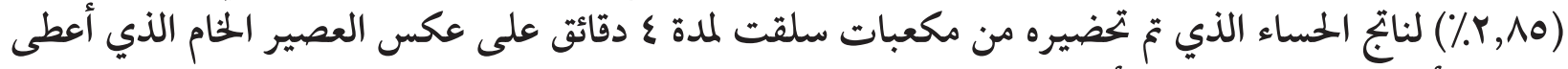

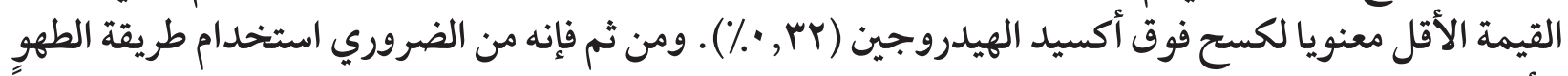

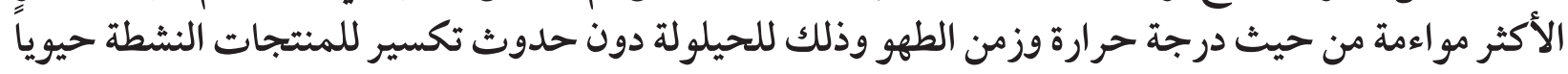

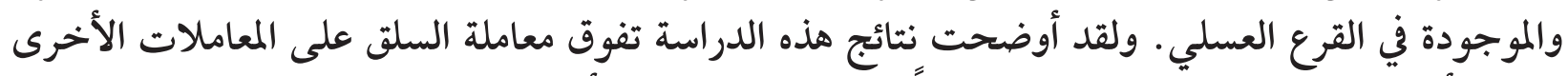

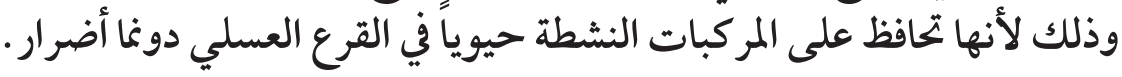

